\title{
Regulation of radial glial process growth by glutamate via mGluR5/TRPC3 and neuregulin/ErbB4
}

\section{Louhivuori, Lauri M.}

2018-01

Louhivuori , L M , Turunen, P M , Louhivuori , V , Yellapragada , V , Nordstrom , T, Uhlen, P \& Akerman, KE 2018 , ' Regulation of radial glial process growth by glutamate via mGluR5/TRPC3 and neuregulin/ErbB4 ' , Glia , vol. 66 , no. 1 , pp. 94-107 . https://doi.org/10.1002/glia.23230

http://hdl.handle.net/10138/237219

https://doi.org/10.1002/glia.23230

unspecified

publishedVersion

Downloaded from Helda, University of Helsinki institutional repository.

This is an electronic reprint of the original article.

This reprint may differ from the original in pagination and typographic detail.

Please cite the original version. 


\title{
Regulation of radial glial process growth by glutamate via mGluR5/TRPC3 and neuregulin/ErbB4
}

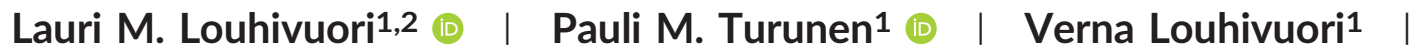 \\ Venkatram Yellapragada $^{1}$ ｜ Tommy Nordström ${ }^{1}$ | Per Uhlén ${ }^{2}$ | Karl E. Åkerman ${ }^{1}$
}

${ }^{1}$ University of Helsinki, Biomedicum, Medicum/Physiology, Helsinki, FIN-00014, Finland

${ }^{2}$ Department of Medical Biochemistry and Biophysics, Karolinska Institutet, Stockholm, SE-171 77, Sweden

\section{Correspondence}

Lauri M. Louhivuori, Biomedicum Helsinki, Faculty of Medicine, Department of Physiology, University of Helsinki, PO Box 63, Fl-00014 Helsinki, Finland.

Email: lauri.louhivuori@helsinki.fi and Karl E. Åkerman, Biomedicum Helsinki, Faculty of Medicine, Department of Physiology, University of Helsinki, PO Box 63, FI00014 Helsinki, Finland.

Email: karl.akerman@helsinki.fi

\section{Funding information}

Finska Läkaresällskapet; Magnus Ehrnroothin Säätiö; Sigrid Juséliuksen Säätiö; Vetenskapsrådet, Grant/Award Number: 2013-3189; Hjarnfonden, Grant/ Award Number: FO2015-0074; Cancerfonden, Grant/Award Number: CAN 2016-801

\begin{abstract}
Radial glial cells play an essential role through their function as guides for neuronal migration during development. Disruption of metabotropic glutamate receptor 5 (mGluR5) function retards the growth of radial glial processes in vitro. Neuregulins (NRG) are activated by proteolytic cleavage and regulate (radial) glial maintenance via ErbB3/ErbB4 receptors. We show here that blocking ErbB4 disrupts radial process extension. Soluble NRG acting on ErbB4 receptors is able to promote radial process extension in particular where process elongation has been impeded by blockade of mGluR5, the nonselective cation channel canonical transient receptor potential 3 (TRPC3), or matrix metalloproteases (MMP). NRG does not restore retarded process growth caused by ErbB4 blockade. Stimulation of muscarinic receptors restores process elongation due to mGluR5 blockade but not that caused by TRPC3, MMP or ErbB4 blockade suggesting that muscarinic receptors can replace $\mathrm{mGluR5}$ with respect to radial process extension. Additionally, NRG/ ErbB4 causes $\mathrm{Ca}^{2+}$ mobilization in a population of cells through cooperation with ErbB1 receptors. Our results indicate that mGluR5 promotes radial process growth via NRG activation by a mechanism involving TRPC3 channels and MMPs. Thus neurotransmitters acting on G-protein coupled receptors could play a central role in the maintenance of the radial glial scaffold through activation of NRG/ErbB4 signaling.
\end{abstract}

\section{KEYWORDS}

calcium, GPCR, migration, neurogenesis, time lapse, transient receptor potential

\section{1 | INTRODUCTION}

During the development of the cerebral cortex a transient population of cells known as the radial glial cells play an essential role through their function as guides for neuronal migration (Kriegstein \& AlvarezBuylla, 2009; Noctor, Flint, Weissman, Dammerman, \& Kriegstein, 2001; Rakic, 1971). In radial glial assisted migration, neurons use radial glial process as scaffolds to shuttle on. The radial glia finally differentiate into astrocytic cells and maintain their role as a scaffold for neuronal migration in adult neurogenesis (Marin \& Rubenstein, 2001). Far from simply serving as a passive role in this process, radial glia constitute a dynamic population of cells that alter their behavior in response to diverse cues from the surrounding environment.

Pauli M. Turunen and Verna Louhivuori contributed equally to this work.
Neuronal cells play a determinant role in regulating and maintaining the function of radial glial cells as migratory guides (Feng \& Heintz, 1995; Gasser \& Hatten, 1990; Hunter \& Hatten, 1995). Although the role of a variety of factors have been implicated in glial-neuron interactions (Cardenas, Kong, Alvarez, Maldonado, \& Leyton, 2014; Sild \& Ruthazer, 2011), studies show that a family of secreted growth factors known as the neuregulins (NRG) play a major role in neuronal migration and radial glia integrity (Anton, Marchionni, Lee, \& Rakic, 1997; LopezBendito et al., 2006; Rio, Rieff, Qi, Khurana, \& Corfas, 1997). This family of structurally related polypeptides (NRG1-4) each contains an epidermal growth factor (EGF) like domain that can activate the v-erb-a erythroblastic leukemia viral oncogene homolog (ErbB) family of tyrosine kinase receptors (Birchmeier, 2009; Buonanno \& Fischbach, 2001; Mei \& Nave, 2014). Interactions between these domains and ErbB receptors can occur in a juxtacrine or paracrine manner after the 
proteolytic activation of NRG by a disintegrin and metalloprotease (ADAM) and/or matrix metalloprotease (MMP) (Ohtsu, Dempsey, \& Eguchi, 2006). ErbB4 receptors are expressed in the subventricular zone (SVZ) during embryonic neurogenesis $(\mathrm{H}$. Li, Chou, Hamasaki, Perez-Garcia, \& O'Leary, 2012). Both NRG and ErbB4 receptors are expressed in radial glial cells during embryonic development (Anton et al., 2004) and NRG knock-down disturbs radial glial growth. Furthermore selective knockdown of radial glial ErbB4 disturbs neuronal migration and placement (Schmid et al., 2003).

G-protein coupled receptors (GPCR) have been demonstrated to transactivate ErbB receptor family members, with most studies focusing on the EGF receptor ErbB1 (Daub, Weiss, Wallasch, \& Ullrich, 1996; Gschwind, Zwick, Prenzel, Leserer, \& Ullrich, 2001; Ohtsu et al., 2006). Activity dependent proteolytic release of NRG1 has also been demonstrated (Ozaki, Itoh, Miyakawa, Kishida, \& Hashikawa, 2004). GPCR transactivation of ErbB seems to require protein kinase C (PKC) (Tsai, Morielli, \& Peralta, 1997) or elevations in intracellular $\mathrm{Ca}^{2+}$ $\left(\left[\mathrm{Ca}^{2+}\right]_{i}\right)$ (Eguchi et al., 1998; Zwick et al., 1997). Hydroxamate based metalloprotease inhibitors, which inhibit ADAM and/or MMP, block EGFR transactivation induced by a variety of GPCR agonists (Asakura et al., 2002; Prenzel et al., 1999; Saito et al., 2002).

The metabotropic glutamate receptor 5 (mGluR5) has emerged as being essential for normal neurogenesis (Di Giorgi Gerevini et al., 2004). We have recently shown that during the early in vitro differentiation process of embryonically derived cortical neural progenitor cells this receptor is predominantly located on radial glial cells and its inhibition disturbs radial process extensions (Jansson et al., 2013; Louhivuori et al., 2015). mGluR5 is coupled to activation of a nonselective cation channel, canonical transient receptor potential 3 (TRPC3) (Berg, Sen, \& Bayliss, 2007; Kim et al., 2003; Louhivuori et al., 2015) which has previously been shown to act as a signal for chemotaxis (Amaral \& PozzoMiller, 2007; H. S. Li, Xu, \& Montell, 1999). Loss of TRPC3 or its inhibition by the selective blocker pyr3 leads to a disruption of radial processes (Louhivuori et al., 2015). Furthermore, disrupting mGluR5/TRPC3 signaling revealed that mGluR5 acting via TRPC3 may be of central importance in radial glial neuronal interactions (Louhivuori et al., 2015).

The aim of this study was to investigate the role of NRG/ErbB receptors in mGluR5/TRPC3 mediated maintenance of radial processes.

\section{I MATERIALS AND METHODS}

\subsection{Cell culture and neuronal differentiation}

Neural progenitor cells (NPCs) were isolated from the walls of the lateral ventricles of embryonic day (E) $14.5129 \mathrm{SvJ} / \mathrm{C} 57 \mathrm{Bl} / \mathrm{N}$ mice, as described previously (Reynolds \& Weiss, 1992). Briefly, cells were grown as free-floating aggregates, known as neurospheres, in Dulbecco's Modified Eagle Medium: Ham's Nutrient Mixture F-12 media (1:1) containing B27 supplement (both from Gibco, Life Technologies Ltd, Paisley, UK), 2 mM L-glutamine, 15 mM 4-(2-hydroxyethyl)piperazine1-ethanesulfonic acid (HEPES), $100 \mathrm{U} / \mathrm{ml}$ penicillin, and $100 \mathrm{U} / \mathrm{ml}$ streptomycin (all from Sigma-Aldrich, St. Louis, MO, USA), in the presence of $10 \mathrm{ng} / \mathrm{ml}$ fibroblast growth factor (FGF) and $20 \mathrm{ng} / \mathrm{ml}$ EGF (both from PeproTech EC Ltd, London, UK), in a $5 \% \mathrm{CO}_{2}$-humidified incubator at $+37^{\circ} \mathrm{C}$. The culture media was refreshed twice a week and growth factors were added three times per week. Cells were passaged by manual trituration at approximately 7-10 day intervals. For neuronal differentiation neurospheres were plated on poly-DLornithine (Sigma-Aldrich) coated culture dishes or cover glasses in the absence of mitogens. Growth factor withdrawal induced spontaneous neuronal differentiation.

\subsection{RNA isolation, cDNA synthesis and PCR}

Total RNA was isolated from proliferating NPCs and NPCs differentiated for 1 and 3 days using the RNeasy Mini Kit (Qiagen, Venlo, Netherlands) according to the manufacturer's instructions. RNA concentration was quantified using a NanoDrop ND8000 spectrophotometer (Thermo Fisher Scientific, MA, USA) and the Transcriptor High Fidelity cDNA Synthesis Kit, random hexamer primer (Roche Applied Science, Basel, Switzerland) were used for cDNA synthesis. The resulting cDNA was amplified in the T100 thermal cycler (BIO-RAD, CA, USA) with the primers for ErbB3, ErbB4, and the neuregulins (NRG1, NRG2, and NRG3).The primers used have been listed in Table 1. The PCR conditions briefly are 1) $\left.95^{\circ} \mathrm{C} 5 \mathrm{~min}, 2\right) 95^{\circ} \mathrm{C} 30 \mathrm{sec}$, 3) $60^{\circ} \mathrm{C}$ for $45 \mathrm{sec}, 4) 72^{\circ} \mathrm{C}$ for $45 \mathrm{sec}$ (steps $2-4$ repeat $35 \times$ ), 5) final extension at $72^{\circ} \mathrm{C}$ for $10 \mathrm{~min}$ and 6) final hold at $4^{\circ} \mathrm{C}$. Adult mouse whole brain cDNA (Takara Clontech, CA, USA) was used as positive control for all the reactions. The polymerase chain reaction (PCR) products were then run on $1.5 \%$ agarose gel with ethidium bromide and the images were captured with the MultilmageTM light cabinet (Alpha Innotech Corporation, CA, USA).

\section{3 | Time-lapse imaging}

Time-lapse imaging of cellular movement was performed in a selfcontained cell-culturing instrument combining phase contrast microscopy, automation and environmental control (Cell-IQ ${ }^{\circledR}$ system, ChipMan Technologies Ltd, Tampere, Finland). The imaging system enables continuous monitoring of adherent cells in two plates in an integrated plate holder. Time lapse images were analyzed with ImageJ (Schneider, Rasband, \& Eliceiri, 2012) and its plugin MJtracker (Meijering, Dzyubachyk, \& Smal, 2012) and the data quantified with Excel (Microscoft, Redmond, WA, USA) and Origin 6.0 (OriginLabCorp).

\section{4 | Calcium imaging}

For the experiments 20-30 neurospheres were plated on poly-DLornithine coated $25 \mathrm{~mm}$ cover glasses and differentiated for the indicated time periods. The cells were then incubated with $4 \mu \mathrm{M}$ fura-2 acetoxymethylester (AM) (Molecular Probes Invitrogen, Life Technologies Ltd, Paisley, UK) at $37^{\circ} \mathrm{C}$ for 20 min in HEPES-buffered media (HBM, pH 7.4) consisting of $137 \mathrm{mM} \mathrm{NaCl}, 5 \mathrm{mM} \mathrm{KCl}, 0.44 \mathrm{mM}$

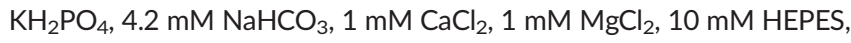
and $10 \mathrm{mM}$ glucose, (all from Sigma-Adlrich). After incubation the cover glass was used as the bottom of an open 1-ml chamber. Subsequently 
TABLE 1 NRG and ErbB primers used for PCR

\begin{tabular}{llll} 
Gene & Forward primer $\left(5^{\prime}-3^{\prime}\right)$ & Reverse primer $\left(5^{\prime}-3^{\prime}\right)$ & Expected size $(\mathbf{b p})$ \\
NRG1 & CATATGCCAGACACCCACAC & ATAACAGGGTCCTGGCCTAA & 260 \\
NRG2 & GTGTGTCACTCGCCTGCTAC & GGGGCAAAGGCTGTCTTAAA & 319 \\
NRG3 & TCTACCACAGCACGGAACAC & GAAAGGGTGACAGGGTCCAG & 202 \\
ErbB3 & GGAGGCTTGTCTGGATTCTG & TCTTCCTCTAACCCTGGTGG & 273 \\
\hline ErbB4 & AAGACGGCTTGTTCATCGGG & ATCGGGGATTTCTCGGGTTG & 286 \\
\hline
\end{tabular}

the chamber was placed under a thermostat controlled holder $\left(37^{\circ} \mathrm{C}\right)$ attached to the microscope (Nikon, TMS inverted microscope, 20× objective) and perfused at $2 \mathrm{ml} / \mathrm{min}$ at $37^{\circ} \mathrm{C}$. Using $340 \mathrm{~nm}$ and $380 \mathrm{~nm}$ light excitation filter changer under the control of the InCytIM2 System (Intracellular Imaging Inc., Cincinnati, $\mathrm{OH}, \mathrm{USA}$ ) and a dichroic mirror (DM430, Nikon) up to 100 cells could be recorded simultaneously. Cells derived from one neurosphere were imaged in each experiment. Light emission was measured through a $510 \mathrm{~nm}$ barrier filter with an integrating charge-coupled device camera (COHU Inc., Poway, CA, USA). A ratioed (340 nm/380 nm) image was acquired each second. The data collected was analyzed with the InCyt 4.5 software (Intracellular Imaging Inc.) and further processed with Origin 6.0 software (OriginLabCorp. Northhampton, MA, USA).

\section{$2.5 \mid \mathrm{Ca}^{2+}$ imaging of embryonic cortical slabs}

Female mice carrying E14.5 fetuses were sacrificed and fetuses were extracted and placed on ice. The fetal brains were then removed and once the cerebral hemispheres were exposed under the dissecting scope, the hemisphere were pinched off with forceps and a neocortical slab was cut out by trimming the cingulate cortex and ganglionic eminences (Janisch et al., 2013). Cortical slabs ( $300 \mu \mathrm{M}$ thick) were then immersed in oxygenated artificial cerebrospinal fluid (ACSF [in $\mathrm{mM}$ ]: $125 \mathrm{NaCl}, 25 \mathrm{NaHCO}_{3}, 1.25 \mathrm{NaH}_{2} \mathrm{PPO}_{4}, 20$ Glucose, $5 \mathrm{KCl}, 2 \mathrm{CaCl}_{2}, 1$ $\mathrm{MgCl}_{2}$ ) at room temperature for at least 1 hour (hr) before imaging. The slabs were then immersed in oxygenated ACSF containing the $\left[\mathrm{Ca}^{2+}\right]_{i}$ indicating dye Fluo-4 AM $(30 \mu \mathrm{M})$ and $0.07 \%$ Pluronic F-127 (Invitrogen) for 30-40 min, rinsed, and placed into the acquisition chamber. Images were acquired by two-photon microscopy on a Zeiss LSM 510 NLO confocal/multi-photon microscope equipped with a Coherent Chameleon Ultra II Titanium-sapphire pulsed laser (Coherent Inc., Santa Clara, CA) and a plan-apochromat $20 \times 1.0$ NA water immersion objective (Olympus, Tokyo, Japan). Slabs were held in place with a nylon mesh grid (Warner Instruments). All images were acquired with a depth of at least $30 \mu \mathrm{m}$. Fluo4-AM was excited at $910 \mathrm{~nm}$ and detected in the wavelength range of 510-600 nm. Oxygenated ACSF in room temperature (RT) was perfused into the chamber continuously during the experiments, and the cortical slab was allowed to rest for 20 mins under these conditions before experiments began. A sequence of 8-bit single $z$-plane images acquired at a $512 \times 512$ pixel resolution $0.5 \mathrm{~Hz}$ (every 2s) under the control of the Zeiss Zen2009 software (Zeiss). At the end of the experiment the images were converted into a movie file (avi) for off line image analysis.
Analysis of the acquired time-lapse movies was performed using FIJI (Schindelin et al., 2012) and custom MATLAB (Mathworks) scripts. To adjust for movements during the image acquisition, linear stack alignment with SIFT (FIJI) were performed prior to region of interest (ROI) selection. Using custom MATLAB scripts, changes in fluorescence intensity over mean fluorescence $(F / \dot{F})$ were calculated for each ROI over the entire time course of the movie. Cells that were lost in focus during the recording period were disregarded in the analysis.

\subsection{Immunocytochemistry}

NPCs were differentiated for 3 days on poly-DL-ornithine coated cover glasses. Briefly, cells were washed with phosphate buffered solution (PBS), fixed with methanol in $-20^{\circ} \mathrm{C}$ for 20 min, washed with PBS, blocked and permeabilized with $10 \%$ normal donkey serum (NDS)/1\% bovine serum albumin (BSA)/0.1\% Triton X-100/PBS for 45 min room tempature, washed with PBS and incubated with primary antibodies overnight $4^{\circ} \mathrm{C}$ in $1 \%$ NDS/1\% BSA/0.1\% TritonX-100/PBS. Cells were washed three times with PBS and incubated with secondary antibodies for $40 \mathrm{~min}$ in the dark at room temperature in the same buffer as used with primary antibodies, washed three times with PBS and mounted with Mowiol (Sigma-Aldrich).

Primary antibodies used were mouse monoclonal anti-microtubuleassociated protein (MAP)-2 (MAB364, 1:500, Millipore, USA), mouse monoclonal anti-ErbB4 (HFR-1, Ab19391, 1:100, Abcam, USA) received as a kind gift from Dr. Klaus Elenius, rabbit polyclonal anti-EAAT1 (excitatory amino acid transporter 1 , also known as glial glutamate-aspartate transporter (GLAST), (ab416, 1:500, Abcam, USA) and rabbit polyclonal anti-HER4/ErbB4 (clone E200, 1:100, Merck Millipore, Germany). Secondary antibodies used were Alexa Fluor 488donkey anti-rabbit IgG (A11008, 1:400), Alexa Fluor 488 donkey anti-mouse IgG (R37114, 1:400),Alexa Fluor 546 donkey anti-goat IgG (A11056, 1:400), Alexa Fluor 546 donkey anti-mouse IgG (A10036, 1:400)(Life Technologies Ltd, USA). Cells were photographed using an Olympus AX70 Provis microscope (Olympus, Espoo, Finland), equipped with fluorescence optics and a charge-coupled device camera (PCO AG, Kelheim, Germany).Brightness and contrast of the obtained images was adjusted with CorelDRAW Graphics Suite X7 (Corel Cooperation, Ontario, Canada).

\section{7 | Data analysis}

Statistical comparisons between groups were performed using oneway ANOVA followed by Tukey post hoc tests. Student's nonpaired 


\section{(a)}

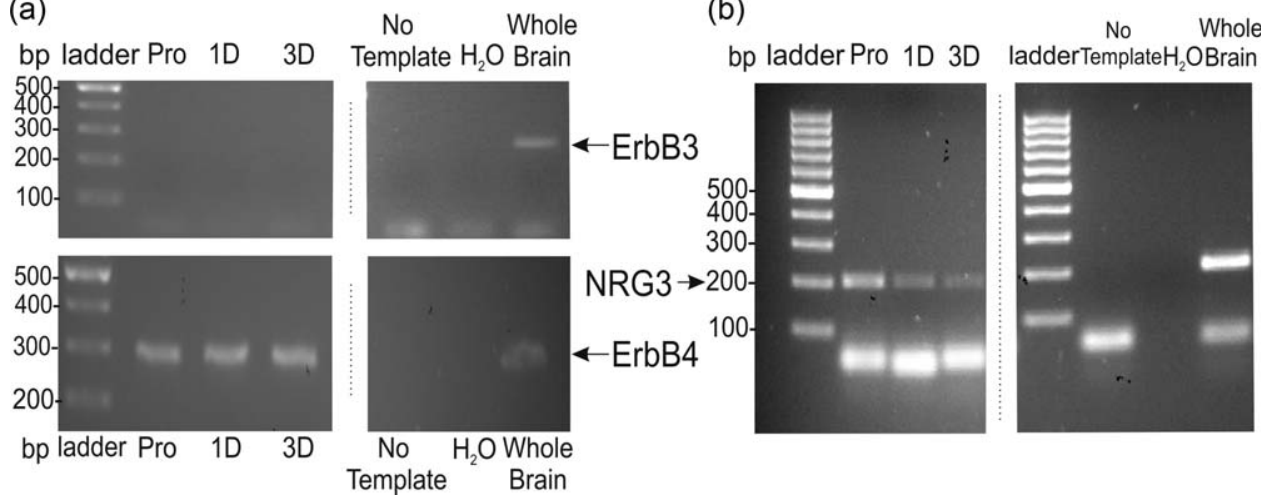

FIGURE 1 Detection of ErbB4 and NRG3 mRNA. In a, PCR showing that ErbB3 mRNA was not detected in proliferating (Pro), 1 day differentiated (1D) or 3 days differentiated (3D) NPCs (top left panel), however with the primers used was detected in adult mouse whole brain cDNA (top right panel). ErbB4 mRNA was detected in proliferating, 1D, and 3D differentiated NPCs (bottom left panel) as well as in the adult mouse whole brain cDNA (bottom right panel). As negative control cDNA template was left out (top and bottom right panels). For presentation purposes intervening gel lanes were removed (dashed lines between left and right panels). In $\mathbf{b}$, mRNA expression of neuregulin 3 (NRG3) was detected in Pro, 1D, and 3D differentiated NPCs (left panel) as well as in adult mouse whole brain cDNA (right panel)

t-test was used in experiments with two groups. Significances are as follows: $p>.05$ ns (not significant); ${ }^{*} p<.05 ;{ }^{* *} p<.01 ;{ }^{* * *} p<.001$.

\section{3 | RESULTS}

\section{$3.1 \mid$ ErbB4 and NRG3 mRNA is expressed in E14.5 NPCs}

NRG has previously been shown to be essential for radial glial structure integrity and growth (Anton et al., 1997; Gierdalski, Sardi, Corfas, \& Juliano, 2005; Schmid et al., 2003; Zheng \& Feng, 2006). To date, the Allen Brain Atlas (Jones, Overly, \& Sunkin, 2009) provides by far the most comprehensive data of gene expression in human and mouse brains. The Allen Developing Mouse Brain Atlas consists of the in-situ hybridizations experimental data of about 2100 genes, 434946 images and 7 developmental stages-E11.5, E13.5, E15.5, E18.5, postnatal (P) 4, P14, and P28 (Thompson et al., 2014). As seen in Supporting Information Figure S1A (image data from the Allen Developing Mouse Brain Atlas: http://brain-map.org) in situ hybridizations of ErbB4 expression in embryonic mice brains at E13.5, E15.5, and E18.5, show a positive signal in the ventricular wall, suggestive of a role for neuregulin receptors in neurogenesis. We set out to determine the expression pattern of the neuregulin receptors ErbB3 and ErbB4 on cortically derived embryonic NPCs from proliferating cultures, as well as neurospheres that have been differentiated for 1 and 3 days (D). No detectable amount of mRNA was observed for ErbB3 receptors (Figure 1A upper panel). However, the mRNA of ErbB4 was detected in both proliferating and differentiated NPCs (Figure 1A lower panel). Both ErbB3 and ErbB4 mRNAs were detected with the primers used in the whole brain CDNA preparation of adult mice.

PCR amplification of the NRG1-3 genes were also tested. NRG3 was detected in both proliferating and differentiated NPCs (Figure 1B). The detection of the NRG1 amplicon was just below the detection limit, appearing and reappearing in different gel runs, however a clear band was seen in the whole brain cDNA preparation of adult mice as shown in Supporting Information Figure S2A. No observable band for NRG2 was found in either proliferating or differentiating NPCs, nonetheless, a clear band was detected in the adult whole brain (Supporting Information Figure S2B).

\subsection{ErbB4 stimulates radial glial process extension and rescues the reduction in radial glial length brought about by MPEP, pyr3 and Gefitinib in E14.5 NPCs}

The neurosphere model allows quantitative analysis of the migratory behavior of radial glial cells and neurons. To evaluate the regulation of radial process extension in vitro, time lapse imaging experiments were performed on differentiating E14.5 derived cortical neurospheres. Removal of mitogens from neurosphere cultures leads to an extension of thick radial processes from the neurosphere (Figure 2A). In Figure $2 \mathrm{~A}$, neuronal cells (denoted with "N") move outside or in close contact with these processes (Jansson et al., 2012). Immunostaining of the thick glial-like processes have previously shown positive staining for radial glial marker GLAST, brain lipid binding protein (BLBP) and Musashi as well as for mGluR5 and ionotropic glutamate receptor GluR3 while the neuronal cells show positive staining for neuronal markers MAP-2, Tuj1 and tyrosine receptor kinase B (TrkB) as well as for ionotropic glutamate receptors GluR1 and GluR2 but hardly any detectable staining for mGluR5 (Jansson et al., 2012, 2013; Louhivuori et al., 2015). The staining of the thick radial processes with GLAST/BLBP and Musashi would suggest that these cells are analogous to radial glia. Antibodies directed against the ErbB4 receptor were used to localize receptor expression (Supporting Information Figure S1). Co-staining of ErbB4 with MAP-2 shows strong ErbB4 staining in neuronal cells (Supporting Information Figure S1B), although only part of the ErbB4 positive cells (green) additionally stained for MAP-2. GLAST staining shows the dense radial glial network (Supporting Information Figure S1C). Although abundant staining for ErbB4 (red) is seen on these processes it is difficult to distinguish radial glial staining of ErbB4 from that of associated neurons. No detectable fluorescence was observed with 
(a)

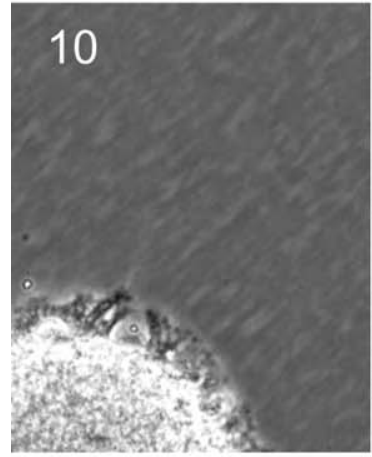

(b)

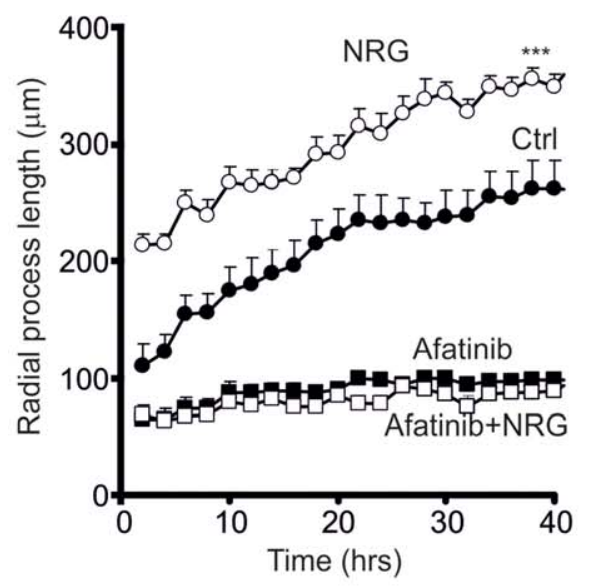

(d)

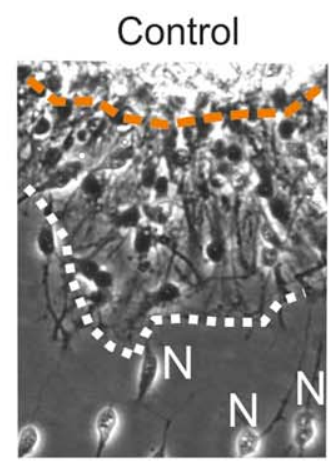

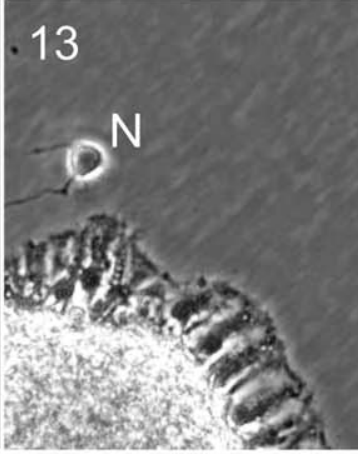
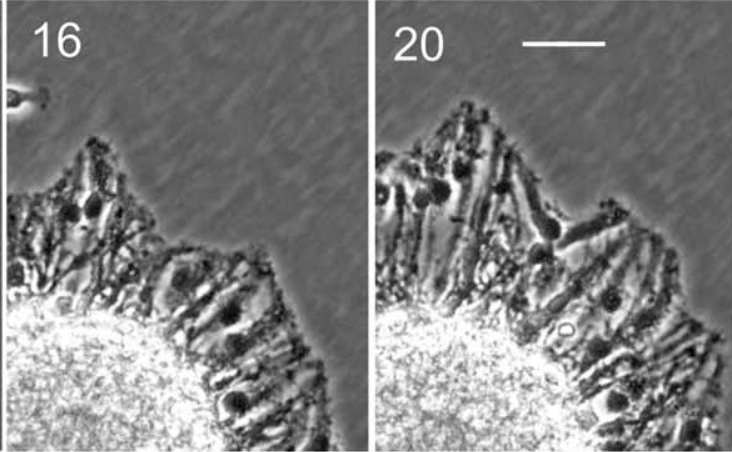

(c)

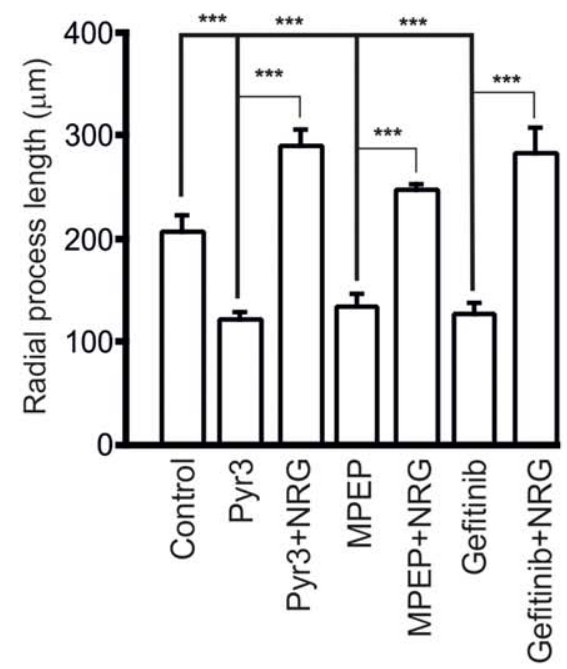

(e)

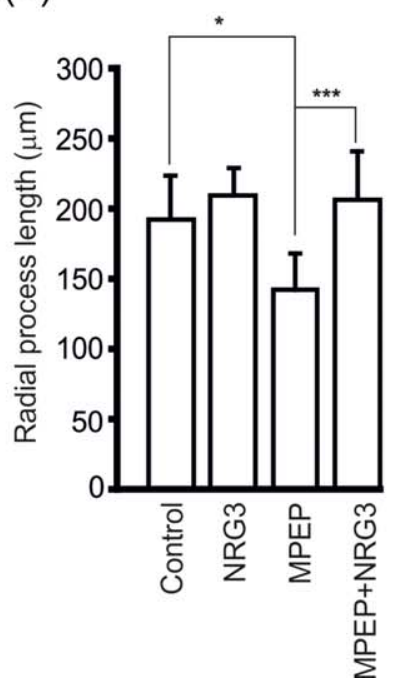

FIGURE 2 Effect of NRG on the length of radial processes. In a, thick radial glial processes extending from a neurosphere. The numbers on the images indicate the time (h) from the start of the experiment, In $\mathbf{b}$, the average length of the radial processes from the edge of the neurosphere starting at $25 \mathrm{hr}$ from the beginning of the experiment. The averages from different experiments: control ( $N=10), N R G(100$ $\mathrm{ng} / \mathrm{ml})(N=12)$, afatinib $(4 \mu \mathrm{M})(N=14)$ and afatinib $+N R G(N=11)$ cultures $\pm S E$ is shown as function of time. Each data point is an average length from 4 different areas on each neurosphere. In c, averages at $40 \mathrm{hr}$ is shown for pyr3 $(1 \mu \mathrm{M})(\mathrm{N}=13), \mathrm{pyr} 3+\mathrm{NRG}(\mathrm{N}=10)$, MPEP $(10 \mu \mathrm{M})(N=10)$, MPEP + NRG $(N=10)$, Gefitinib $(100 \mathrm{nM})(N=11)$ and Gefitinib + NRG treated cultures $\pm S D$. In d, representative phase contrast images showing radial glia elongation in control, MPEP, and MPEP + NRG3 treated cells. Dotted lines outlines the border created by the neurosphere and by the tips of the processes. Neuronal cells are denoted by N. In e, averages at 40 hr is shown for control $(N=5)$, NRG3 $(100 \mathrm{ng} / \mathrm{ml})(\mathrm{N}=11)$, MPEP $(10 \mu \mathrm{M})(N=11)$, MPEP + NRG3 $(N=11)$. Scale bars for images $=50 \mu \mathrm{m}$ 
negative controls without primary antibody at the same exposure times as with the primary antibody.

To assess whether NRG/ErbB4 is involved in the disturbances brought about by disrupting mGluR5/TRPC3 signaling, neurospheres cultured in the presence of blockers of this pathway (MPEP, a blocker of mGluR5 and pyr3, a blocker of TRPC3) were stimulated with 100 $\mathrm{ng} / \mathrm{ml}$ of the EGF domain of NRG1 and NRG3, which is sufficient to induce ErbB4 receptor activation (Beerli \& Hynes, 1996; Graus-Porta, Beerli, Daly, \& Hynes, 1997). The average length of the processes from the edges of the neurospheres (shown as the distance between broken line and dotted line in Figure 2D) was determined as a function of time (Figure 2B). NRG1 treatment significantly increased the length of the radial processes. The ErbB1/4 blocker afatinib on the other hand significantly reduced process extension. As shown previously MPEP and pyr3 also significantly reduced process length. NRG had no effect on the radial processes in the presence of afatinib. NRG1, however, restored the radial process extension in MPEP and pyr3 treated cells (Figure 2C). A synthetic peptide based on the active domain of NRG3 also restored the radial process elongation disturbed by MPEP (Figure $2 \mathrm{D}, \mathrm{E})$. Due to the commercial availability of NRG1, we proceeded to use the EGF domain of NRG1 for later experiments. Since afatinib also inhibits the kinase activity of ErbB1 (EGF receptor) we cultured NPCs in the presence of the ErbB1 blocker gefitinib. Surprisingly blocking ErbB1 with gefitinib also had a drastic effect on radial process length and this reduction was similarly rescued by ErbB4 stimulation with NRG (Figure 2C).

\subsection{Stimulation of muscarinic receptors with oxotremorine $\mathrm{M}$ restores the MPEP-induced reduction in radial process length}

The culture medium (see methods section) generally used for neuronal progenitor cell culture contains $25 \mu \mathrm{M}$ glutamate as an essential component (according to the manufacturers information). This concentration is enough to activate mGluR5. The receptor is coupled to the $G_{q}$ / phospholipase $C$ - $\beta$ (PLC $\beta$ ) system leading to $\mathrm{Ca}^{2+}$ mobilization (Brauner-Osborne \& Brann, 1996; Oettling, Gotz, \& Drews, 1992). Mouse and human neural progenitor cells show robust responses also to $\mathrm{G}_{\mathrm{q}}{ }^{-}$ protein coupled muscarinic receptor stimulation (Castren et al., 2005; Karkkainen, Louhivuori, Castren, \& Akerman, 2009). It was therefore of interest to test whether muscarinic receptor stimulation is able to replace mGluR5 with respect to radial glial process elongation. The $\mathrm{Ca}^{2+}$ response of a radial glial cell to the mGluR5 agonist 3,5-dihydroxyphenylglycine (DHPG) and the muscarinic receptor agonist oxotremorine $\mathrm{M}$ (oxoM) is shown in Figure 3A. In Figure 3B the correlation between the DHPG-induced and oxoM-induced $\mathrm{Ca}^{2+}$ elevation is shown in areas of radial glial processes. Note the linear correlation between the two responses in the radial processes. As shown in Figure $3 \mathrm{C}$ oxoM caused a significant increase in radial process extension in MPEP treated cells to the same length as in control cells. This effect was blocked by pyr3, afatinib and gefitinib (Figure $3 \mathrm{C}$ ), suggesting that $\mathrm{G}_{\mathrm{q}}$ coupled muscarinic receptors recruit similar signaling components as mGluR5 to direct radial glial growth.

\subsection{Matrix metalloproteinase inhibition diminishes radial glial growth}

Ectodomain shedding of membrane anchored NRG by MMP/ADAM proteases allows for the interaction of NRG with ErbB receptors (Mei $\&$ Xiong, 2008). Neurospheres were cultured in the presence of ilomastat, a pan inhibitor of MMP/ADAM proteases. As seen in Figure 3D ilomastat $(1 \mu \mathrm{M})$ significantly reduced radial glia process length. Administration of NRG in the presence of ilomastat restored the radial glia process length to control levels, demonstrating that unbound NRG plays an integral part in mediating radial glia growth. OxoM, however, which restored radial process growth in the presence of MPEP (see above) was unable to restore radial process growth in the additional presence of ilomastat (Figure 3D).

\subsection{Neuronal contacts promote radial glia growth}

Image sequences of radial processes in contact or devoid of contact with neurons were analyzed to evaluate the role of neuronal cells in radial process extension. As seen in the panels of Figure $4 \mathrm{~A}$, once a neurite on a migrating neuronal cell is attracted to/by radial process the typically bipolar neuronal soma elongates and begins to dynamically extend and retract neurites making multiple cell-to-cell contacts (Supporting Information Video S1). This interaction appears to attract and promote the growth of radial glia process as seen in Figure 4B. Radial glia cells that lacked neuronal contact displayed a more stunted process growth (Figure 4C,D).

\subsection{NRG induced calcium elevations in E14.5 NPCs during the early differentiation phase}

NRG acting on ErbB2/ErbB3 receptors have been shown to induce $\mathrm{Ca}^{2+}$ rises in Schwann precursor cells in a PLC $\gamma$ dependent manner (Kao et al., 2009) and several studies have demonstrated that NRG/ ErbB signaling is able to modulate glutamergic $\mathrm{Ca}^{2+}$ signaling (Falls, 2003; Ozaki, Sasner, Yano, Lu, \& Buonanno, 1997). As such we were interested to investigate whether ErbB4 receptor activation could induce $\left[\mathrm{Ca}^{2+}\right]_{i}$ changes in cortical NPCs. We proceeded to elucidate the effect ErbB4 stimulation in proliferating, 1D and 5D differentiated NPCs. Furthermore we have previously shown in a number of our studies that radial glial cells express the mGluR5 receptor giving a response to DHPG, whilst cells with a neural fate do not but respond to kainate an agonist of AMPA/kainate receptors (Jansson et al., 2012; Karkkainen et al., 2009; Louhivuori et al., 2015, 2013).

Stimulating ErbB4 receptors with the EGF domain of NRG at a concentration of $(100 \mathrm{ng} / \mathrm{ml})$ caused no detectable rise in $\left[\mathrm{Ca}^{2+}\right]_{i}$ in any of the proliferating cells $(n=353, N=5)$ (Figure 5A upper panel). At 1D differentiation, $27.7 \pm 4.7 \%(n=293, N=5)$ of the cells displayed a calcium response to NRG exhibiting a clear and immediate increase in $\left[\mathrm{Ca}^{2+}\right]_{i}$ followed by a decay and stable elevation of $\left[\mathrm{Ca}^{2+}\right]_{i}$ (Figure 5A middle panel and Figure 5B). Nearly all the cells (>98\%) that responded to NRG gave a response to DHPG, with only a few cells not responding to DHPG but to kainate $(<2 \%)$. The cells that displayed the NRG/kainate responses were positioned very close to the 
(a)

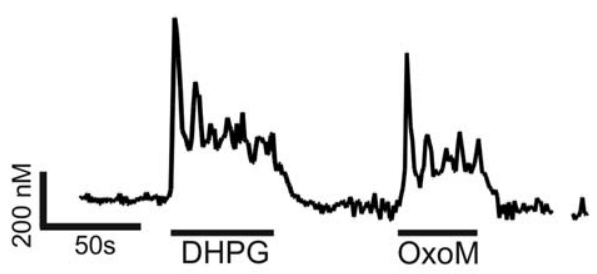

(c)

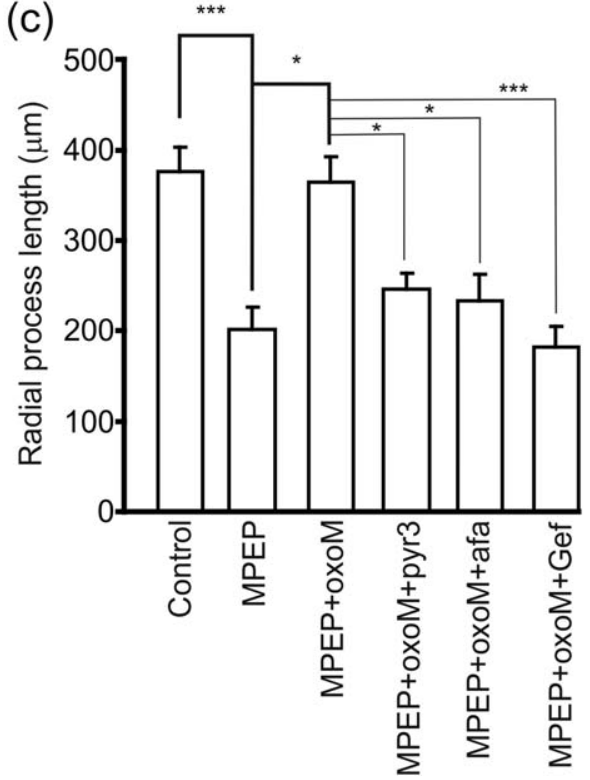

(b)

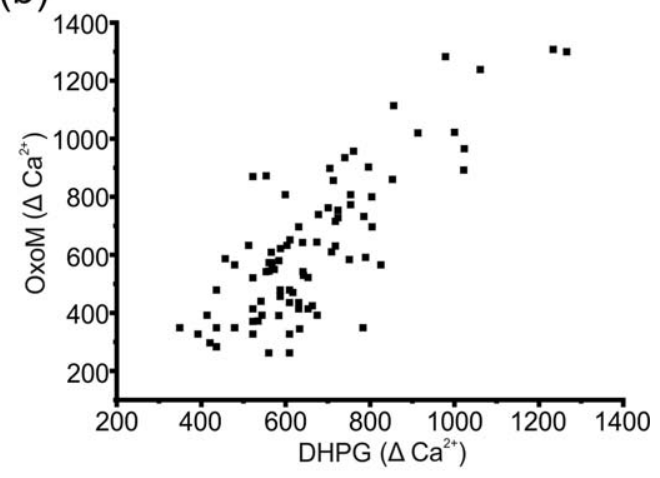

(d)

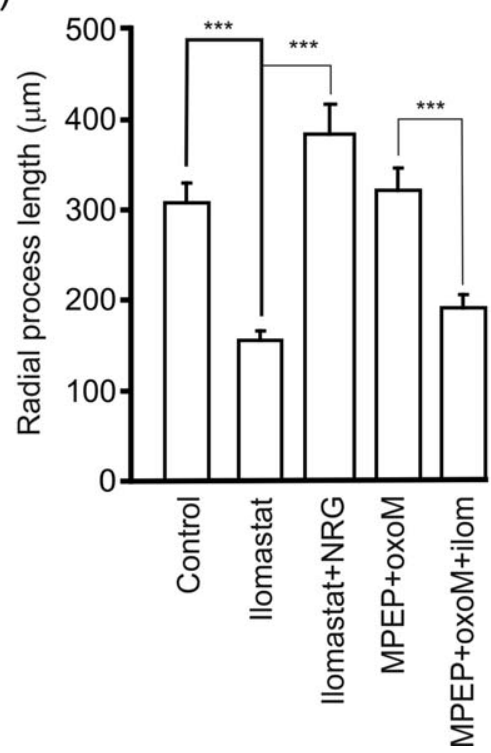

FIGURE 3 Effect of muscarinic receptor stimulation with OxoM on radial process extension. In a, representative $\mathrm{Ca}^{2+}$ trace for 1 day differentiated NPCs displaying responses to DHPG $(10 \mu \mathrm{M})$ and OxoM $(10 \mu \mathrm{M})$. In $\mathbf{b}$, the $\left[\mathrm{Ca}^{2+}\right]_{i}$ changes of cells that responded to both DHPG and OxoM were plotted, displaying a linear correlation (Pearson's $r=0.82$ ). In $c$, and $d$, the average length of the radial processes from the edge of the neurosphere after $25 \mathrm{hr}$ of differentiation. The number of experiments in c, controls $(N=7), M P E P(N=7)$, MPEP + OxoM $(N=7), M P E P+O x o M+\operatorname{pyr} 3(N=7), M P E P+O x o M+$ afatinib $(N=7), M P E P+O x o M+$ pyr3 + gefitinib $(N=7)$. In $D$, controls $(N=5)$, ilomastat $(N=6)$, ilomastat + NRG $(N=6)$, MPEP + OxoM $(N=6)$, and MPEP + OxoM + ilomastat $(N=6)$. Error bars show $\pm S D$

neurosphere. After 5D of differentiation, no detectable change in $\left[\mathrm{Ca}^{2+}\right]_{i}$ to ErbB4 stimulation was found $(n=630, N=7$ ) (Figure $5 \mathrm{~A}$ lower panel). Stimulating ErbB1 with EGF at a concentration of $20 \mathrm{ng} /$ $\mathrm{ml}$ (same as culturing conditions) $\left[\mathrm{Ca}^{2+}\right]_{i}$ responses were recorded in proliferating cells, as well as in both $1 D$ and $5 D$ differentiated NPCs (Figure 5A,B). All the cells that responded to DHPG also responded to EGF. A minor linear correlation was also observed between the NRG and EGF responses (Pearson's $r$ value $=0.59$ ) (Supporting Information Figure S2).

Afanitib $(4 \mu \mathrm{M})$ which inhibits the ErbB1/4 receptor tyrosine kinase activity abolished the $\left[\mathrm{Ca}^{2+}\right]_{i}$ response to ErbB4 stimulation (Figure 6A). Since the effect of gefitinib was seen on radial glial cells and NRG $\mathrm{Ca}^{2+}$ responses were recorded on a subpopulation of DHPG responding cells we ran $\mathrm{Ca}^{2+}$ imaging on 1D NPCs to determine gefitinibs effect. Gefitinib at a concentration that specifically blocks ErbB1, significantly inhibited the NRG/ErbB4 induced rise in $\left[\mathrm{Ca}^{2+}\right]_{i}$ in a reversible manner (Figure 6B) suggesting the ErbB1 receptors are required for the calcium response to NRG.

Tyrosine kinase receptors like ErbB1 typically couple to PLC $\gamma$ causing release of $\mathrm{Ca}^{2+}$ from intracellular stores coupled to influx of $\mathrm{Ca}^{2+}$ through capacitative $\mathrm{Ca}^{2+}$ entry. ErbB4 stimulation with NRG in the absence of extracellular $\mathrm{Ca}^{2+}$ caused a transient rise in $\left[\mathrm{Ca}^{2+}\right]_{i}$ (Figure $6 \mathrm{C}$ ). Re-addition of extracellular $\mathrm{Ca}^{2+}$ restored the $\left[\mathrm{Ca}^{2+}\right]_{i}$ stable elevation (Figure $6 \mathrm{C}$ ). In the presence of 2-aminoethoxydiphenylborate (2-APB) $(1 \mu \mathrm{M})$, a blocker of store operated Orai channels (Kukkonen, Lund, \& Akerman, 2001), the $\left[\mathrm{Ca}^{2+}\right]_{i}$ stable elevation was significantly attenuated when extracellular $\mathrm{Ca}^{2+}$ was introduced back to the bathing solution (Figure 6D,E). The $\mathrm{Ca}^{2+}$ elevations seen in response to NRG thus shows typical features of $\mathrm{PLC} \beta / \gamma$ signaling.

Since 2-APB is not selective for Orai channels and may block or stimulate other receptor operated channels depending on concentrations used (Xu et al., 2005) reviewed in (Harteneck \& Gollasch, 2011) 
(a)
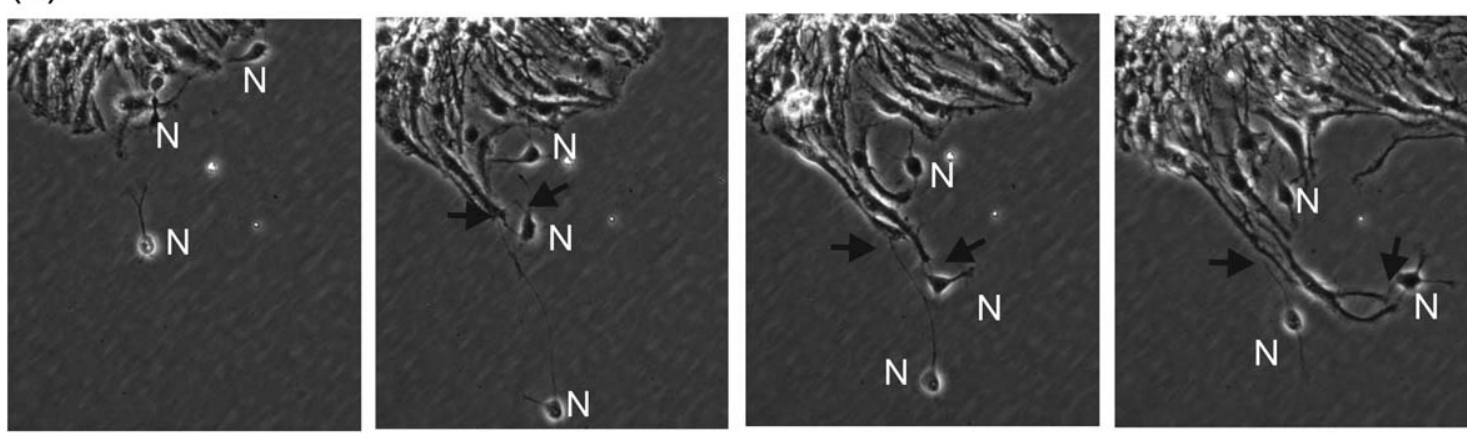

(b)

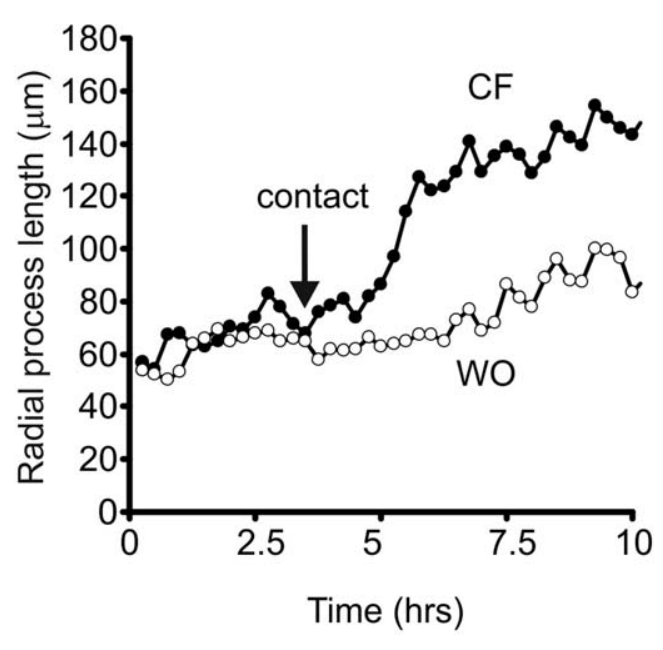

(c)

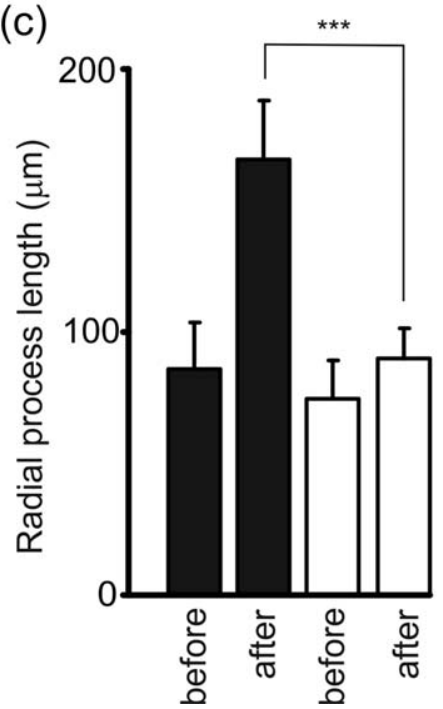

(d)

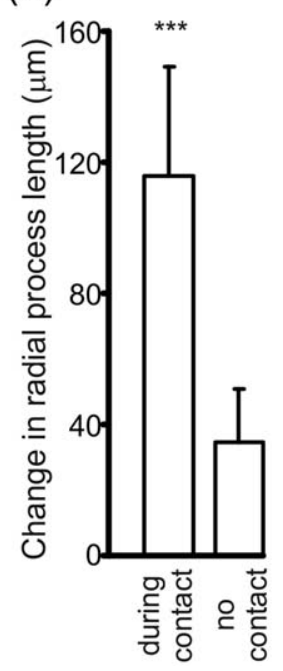

FIGURE 4 Cell-cell interaction promotes radial process growth. In a, a series of phase contrast images displaying the dynamic interaction between migrating neuronal cells and radial glia. Radial glial process growth is promoted by the interaction with neuronal cells (N). Black arrows depict representative contact points. In b, radial glia elongation $(\mu \mathrm{m})$, measured as the change in distance from origin, plotted against time (h). The filled circles display radial glia that are in contact with neuronal cells (contact formation indicated by black arrow, CF), whilst unfilled circles represent adjacent radial glia area without direct neuronal contact (WO). Analysis was performed after 25 hr. In c, The length of the radial processes before and $5 \mathrm{hr}$ after contact with neuron $( \pm S D, N=18)$. In $\mathrm{d}$, the increase in the length of connected or nonconnected radial processes during a $10 \mathrm{hr}$ period $( \pm S D, N=18)$

other blockers were tested. Low concentrations of lanthanides like $\mathrm{Gd}^{3+}$ selectively block Orai channels while other types of channels are either activated or inhibited at higher lanthanide concentrations ( $\mathrm{Xu}$ et al., 2005; Yeromin et al., 2006). Addition of $\mathrm{Gd}^{3+}$ during the sustained phase of $\mathrm{Ca}^{2+}$ elevation in the presence of extracellular $\mathrm{Ca}^{2+}$ caused a partial and reversible inhibition of the $\mathrm{Ca}^{2+}$ elevation (Figure 7A). SKF96365 blocks some receptor operated channels (Merritt et al., 1990) including thapsigargin stimulated $\mathrm{Ca}^{2+}$ entry (Larsson et al., 2005). A partial inhibition of the sustained $\mathrm{Ca}^{2+}$ elevation was also obtained with this compound (Figure 7B). A complete block of the $\mathrm{Ca}^{2+}$ elevation occurred upon subsequent addition of the pyrazole compound pyr2 (Figure 7B). Pyrazole compounds block nonselective TRPC cation channels (Kiyonaka et al., 2009). While pyr2 is nonselective blocking a variety of channels including Orai channels pyr3 is selective for TRPC3 channels (Kiyonaka et al., 2009) reviewed in (Harteneck \& Gollasch, 2011). As shown in Figure 7C pyr3 had a modest effect on NRG stimulated $\mathrm{Ca}^{2+}$ elevation while pyr2 totally reversed the sustained $\mathrm{Ca}^{2+}$ response. Statistics for inhibition of the NRG stimulated
$\mathrm{Ca}^{2+}$ elevation are shown in Figure 7D. On average $\mathrm{Gd}^{3+}$ and SKF96365 caused about 50\% inhibition while the effect of pyr 2 was almost total and pyr3 had a variably small effect.

\section{7 | NRG-stimulated $\mathrm{Ca}^{2+}$ elevations in embryonic E14.5 cortical slabs}

In order to evaluate whether the data described above on neurosphere-derived cells is of relevance, in vivo experiments were also performed with neocortical E14.5 brain sections using the $\mathrm{Ca}^{2+}$ probe fluo-4 (see methods section for experimental detail). Fluorescence responses to application of NRG were seen in about $6.0 \pm 0.91 \%$ ( $n=595$, N3) of the regions of interest on the apical surface of the neocortical slab. An average of the responses of DHPG, NRG and kainate in these regions are shown in Figure 8A. While the response to DHPG usually consisted of a rapid peak and a slowly declining sustained phase the response to NRG appeared slower due to a delayed response in many cells. The response to kainate was rapid and robust. 

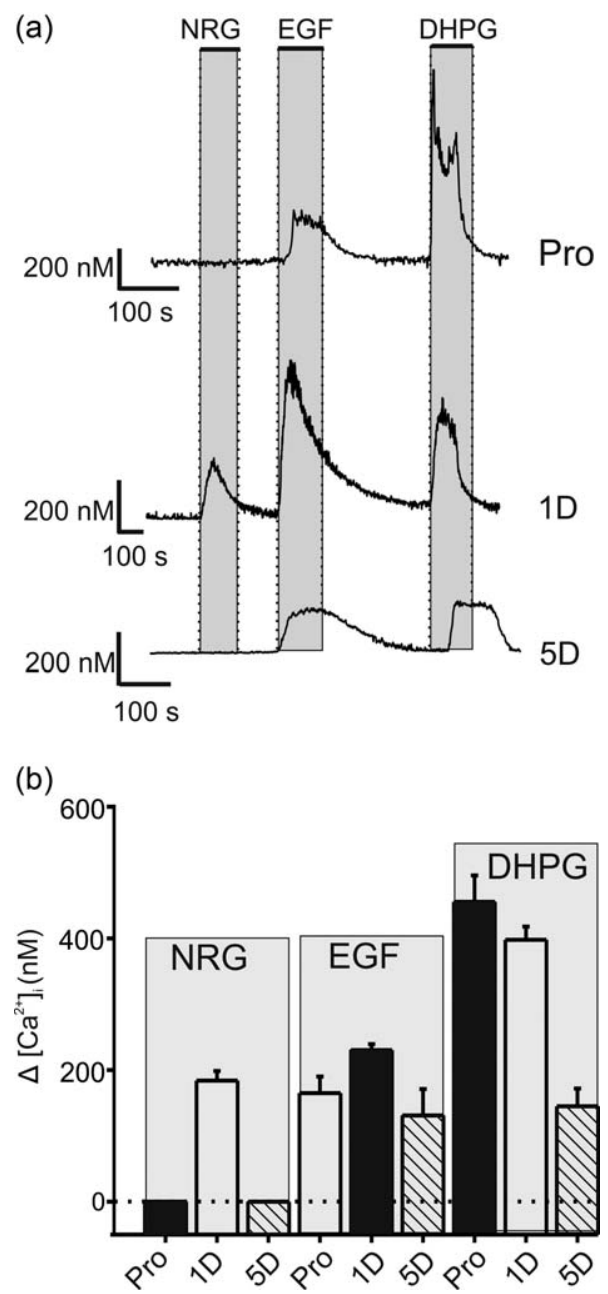

FIGURE 5 Effect of NGR1 on $\left[\mathrm{Ca}^{2+}\right]_{i}$. In a, representative $\mathrm{Ca}^{2+}$ traces of proliferating (Pro; top panel), 1 day differentiated (1D; middle panel), and 5 days differentiated (5D; bottom panel) NPCs challenged with the EFG domain of NRG1 (100 ng/ml), EGF (20 $\mathrm{ng} / \mathrm{ml})$, and DHPG $(10 \mu \mathrm{M})$. In $\mathbf{b}$, the average $\left[\mathrm{Ca}^{2+}\right]_{i}$ responses to NRG, EGF, and DHPG in Pro $(n=353, N=5), 1 D(n=293, N=5)$, and $5 \mathrm{D}$ differentiated $(n=630, N=7) \mathrm{NPCs}$. Error bars show $\pm \mathrm{SE}$

The spatial distribution of these responses with respect to the different responses were then analyzed. Cells responding to both DHPG and kainate were the most abundant accounting for over $60 \%$ of the responding cells. Cells that responded to NRG also responded to DHPG and kainate, respectively (Figure 8B).

\section{4 | DISCUSSION}

This study can be briefly summarized with the following points: 1) in embryonically derived cortical neural progenitor cells ErbB4 receptors are the prevalent transducers of NRG signaling 2) disrupting mGluR5/ TRPC3 signaling impedes radial glial growth which is rescued by NRG/ ErbB4 signaling thus strongly supporting the notion that NRG/ErbB4 works downstream of mGluR5/TRPC3 to maintain and direct normal radial glial growth 3) Blocking of ErbB1/ErbB4 receptors results in disruption of the radial glial scaffold in a similar way as mGluR5/TRPC3 blockade 4) ErbB4 is able to cooperate with ErbB1 receptors to mediate $\mathrm{Ca}^{2+}$ responses in a sub-population of cortical progenitor cells at the early onset of their differentiation and migration. Our results thus suggest that the $\mathrm{G}_{\mathrm{q}}$-coupled receptor mGluR5, acting via TRPC channel proteins regulate the activity of NRG which in turn promotes radial glial process elongation via the tyrosine kinase receptor ErbB4. Since also

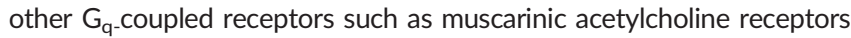
can replace mGluR5 our results favor a scenario that young neurons can promote growth of their radial glial scaffold through release of neurotransmitters such as glutamate and acetylcholine causing transactivation of ErbB receptors via Gq-coupled GPCRs. The apparent increase in growth of radial processes upon interaction with neuronal cells would support such a mechanism.

The abundant presence of ErbB4 receptors and the lack of ErbB3 expression in embryonically derived cortical progenitor cells suggest that the actions of NRG occurs via ErbB4. This is in agreement with previous ErbB receptor expression studies done on mice where ErbB3 mRNA is hardly detected in cortical regions during early brain development whereas ErbB4 expression was most prominent, becoming more restricted postnatally (Bean et al., 2014; Fox \& Kornblum, 2005).

Neuregulins signaling occurs via soluble or several different membrane bound forms (Mei \& Xiong, 2008). A role of NRG1 in radial glial process extension in slices has previously been described (Anton et al., 1997; Schmid et al., 2003). A significant elongation of radial processes was obtained also in this study under basal conditions. ErbB4 receptors and neuregulin are expressed in the SVZ during neurogenesis $(\mathrm{H} . \mathrm{Li}$ et al., 2012). ErbB4 expression in isolated embryonic radial glial cells has been demonstrated using immunocytochemistry (Anton et al., 1997).

Blocking mGluR5 and TRPC3 caused a drastic reduction in radial process growth (Jansson et al., 2012; Louhivuori et al., 2015). As shown here, NRG was able to restore the growth of radial glial processes. This together with the finding that the ErbB4 blocker afatinib reduced process extension would suggests that NRG/ErbB4 signaling pathway works downstream of mGluR5/TRPC3 to maintain the radial glial scaffold. Activating metabotropic muscarinic receptors with oxoM, in the presence of the mGluR5 blocker MPEP, was also able to normalize radial glial growth. Inhibiting TRPC3 with pyr3 however prevented the oxoM rescue, signifying that both $\mathrm{G}_{\mathrm{q}}$ coupled receptors utilize this nonselective cation channel to maintain and promote radial glial growth.

Ecotodomain shedding of ErbB ligands can be regulated by $\mathrm{Ca}^{2+}$ (reviewed in (Ohtsu et al., 2006). Interestingly we have previously shown that pyr3 inhibits the mGluR5 induced $\mathrm{Ca}^{2+}$ influx (Louhivuori et al., 2015). A lack of sheddase activation could thus explain the reduction in radial glial process elongation seen with mGluR5/TRPC3 blockade. Furthermore ilomastat, a matrix metalloprotease inhibitor, which has previously been shown to block GPCR mediated transactivation of ErbB receptors through proteolysis (Santiskulvong \& Rozengurt, 2003) also reduced the length of radial processes. Since NRG was able to reverse the effect of ilomastat it appears likely that activation of proteolytic cleavage of ErbB receptor ligands is a downstream effector mechanism of mGluR5/TRPC3 activation. 
(a)

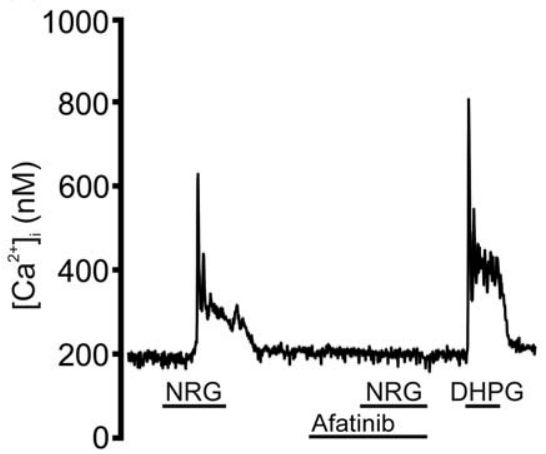

(c)

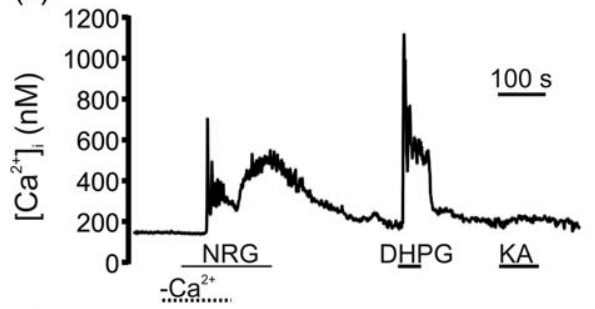

(d)

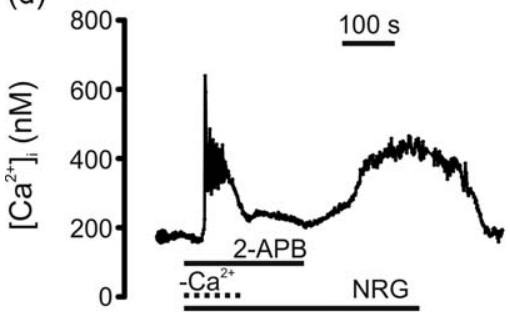

(b)

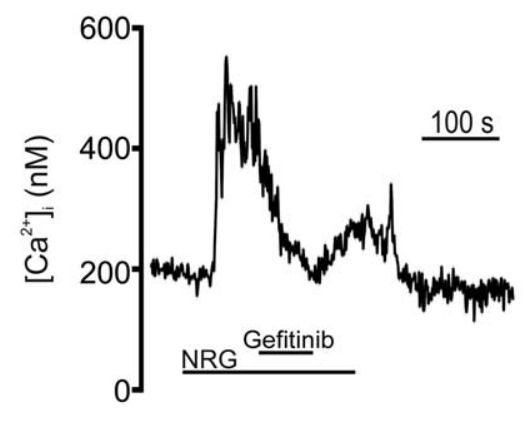

(e)

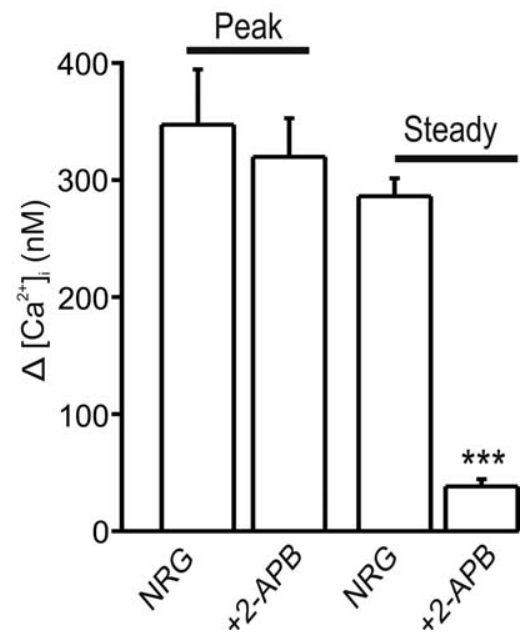

FIGURE 6 Effect of afatinib, gefitinib and 2-APB on $\left[\mathrm{Ca}^{2+}\right]_{i}$. In a, a representative $\mathrm{Ca}^{2+}$ trace of a 1D differentiated NPC's response to ErbB4 stimulation with NRG $(100 \mathrm{ng} / \mathrm{ml})$ which was irreversibly blocked by afatinib $(4 \mu \mathrm{M})$. In $\mathbf{b}$, the reversal of the $\mathrm{Ca}^{2+}$ elevation by the ErbB1 blocker Gefitinib (100 nM), In c, ErbB4 activation caused an increase in the $\left[\mathrm{Ca}^{2+}\right]_{i}$ in the absence of extracellular $\mathrm{Ca}^{2+}$. Upon the readdition of extracellular $\mathrm{Ca}^{2+}$, the $\left[\mathrm{Ca}^{2+}\right]_{i}$ stable elevation was restored. The stable elevation of $\left[\mathrm{Ca}^{2+}\right]_{i}$ after readdition of extracellular $\mathrm{Ca}^{2+}$ was sensitive to the Orai channel blocker 2-APB $(1 \mu \mathrm{M})$ as shown in $\mathrm{d}$. In e, the average $\mathrm{Ca}^{2+}$ responses in both the peak and steady state phase of the $\mathrm{Ca}^{2+}$ response to NRG in the presence of 2-APB $(n=63, \mathrm{~N}=3)$ Error bars show $\pm \mathrm{SE}$

Even though our results demonstrate the additional involvement of ErbB1 receptor in radial glial maintenance, blocking ErbB1 receptor with its specific blocker gefitinib resulted in a similar disruption in the radial glial scaffold as did with blocking both ErbB1/ErbB4 with afatinib. However NRG stimulation was able to rescue the ErbB1 block (gefitinib), but was not able to restore the radial glial change when blocking ErbB1/4 with afatinib, signifying the role of ErbB4 in radial process extension. This would suggest that both ErbB1 and ErbB4 receptors are independently involved in the maintenance of radial glial processes.

While most if not all radial glial cells showed a robust $\mathrm{Ca}^{2+}$ response by ErbB1 stimulation with EGF only a small proportion of the cells responded to NRG stimulation at an early time point. To the knowledge of the authors this is the first demonstration of a $\mathrm{Ca}^{2+}$ response brought about by NRG stimulation in embryonically derived cortical cells. PLC $\gamma$, the likely mediator of the $\mathrm{Ca}^{2+}$ response, is not a downstream target of ErbB4 (Mei \& Xiong, 2008). The $\mathrm{Ca}^{2+}$ elevation to NRG observed in this study shows typical features of PLC $\beta / P L C \gamma$ signaling e.g. intracellular release and sustained influx indicating release from $\mathrm{IP}_{3}$ sensitive stores and store replenishment via orai channels.
The influx response was typically blocked by 2-APB and low concentrations of $\mathrm{Gd}^{3+}$.

Since the $\mathrm{Ca}^{2+}$ response to NRG was blocked both by afatinib and gefitinib both ErbB1 and ErbB4 receptors would be involved. This indicates that in some cells activated ErbB4 cross activates ErbB1 receptors to mediate $\mathrm{Ca}^{2+}$ responses in a subpopulation of DHPG responsive cells. The crosstalk between different ErbB receptors is highly dose dependent (Pinkas-Kramarski, Shelly, Glathe, Ratzkin, \& Yarden, 1996). In this context the linear correlation between EGF and NRG response suggest that a transit population containing both ErbB receptor populations at high density is responsible for the NRG stimulated $\mathrm{Ca}^{2+}$ response. This data further supports a role of both ErbB receptors in radial glial function.

$\mathrm{Ca}^{2+}$ responses to NRG could also be observed in a small population of neuronal cells in acute neocortical E14.5 brain slabs. This suggests that $\mathrm{Ca}^{2+}$ elevation to NRG is a native response also in vivo, albeit probably in a narrow time window.

Interestingly NRG3 was found to be the dominant neuregulin in E14.5 embryonic neural progenitor cultures. Less is known about the 
(a)

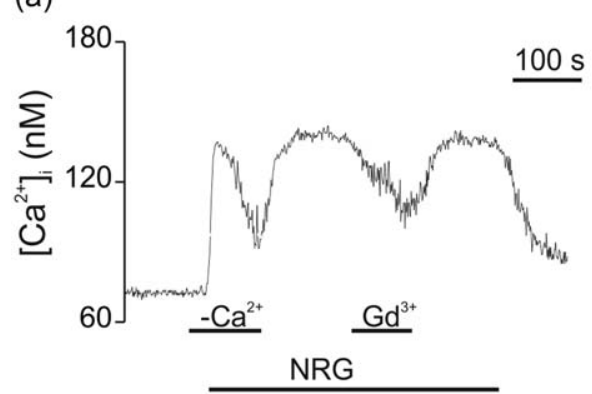

(c)

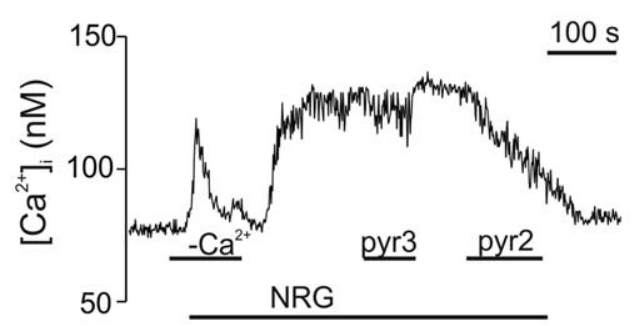

(b)

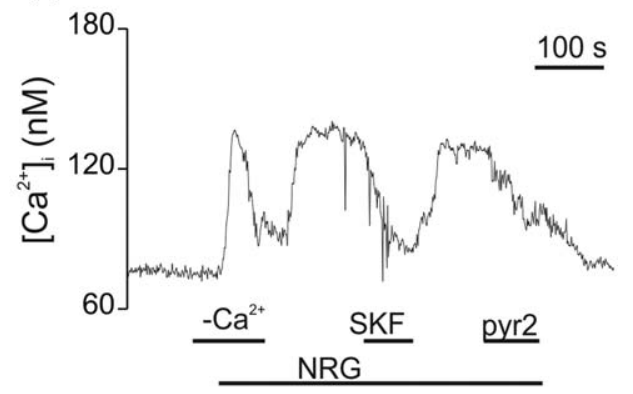

(d)

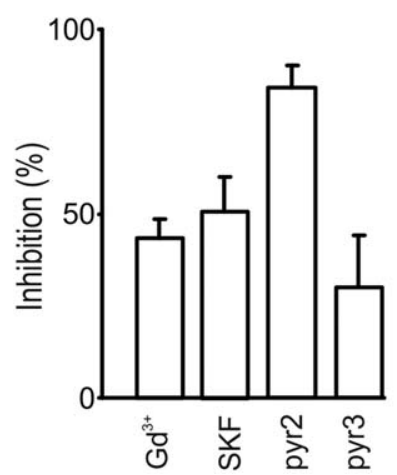

FIGURE 7 Effect of blockers on the sustained NRG induced increase in $\left[\mathrm{Ca}^{2+}\right]_{i}$. Experiments were performed in a phosphate and bicarbonate free medium otherwise identical to that described in methods. In a, a representative $\mathrm{Ca}^{2+}$ trace of a 1D differentiated NPC's

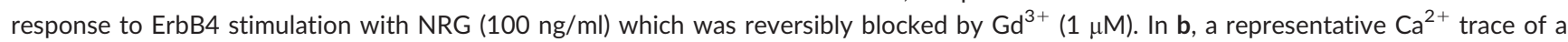
1D differentiated NPC's response to ErbB4 stimulation with NRG (100 ng/ml) which was reversibly blocked by SKF96365 (5 $\mu$ M) and irreversibly blocked by pyr2 $(10 \mu \mathrm{M})$. In c, a representative $\mathrm{Ca}^{2+}$ trace of a 1D differentiated NPC's response to ErbB4 stimulation with NRG $(100 \mathrm{ng} / \mathrm{ml})$ which was not blocked by pyr3 (1 $\mu \mathrm{M}$, concentration which totally blocks TRPC3) but irreversibly blocked by pyr2 (10 $\mu \mathrm{M})$. In $\mathrm{d}$, statistics for the inhibition of $\mathrm{Ca}^{2+}$ elevations by $\pm S D, \mathrm{Gd}^{3+}(N=6)$, SKF96365 $(N=3)$, pyr2 $(N=3)$, and pyr3 $(N=3)$

role of NRG3 than NRG1. As shown here soluble NRG3 was also able to rescue the reduction in radial process length caused by mGluR5/TRPC3 blockade. Previous studies have demonstrated that NRG3/ErbB4 signaling increases neurite outgrowth (Plani-Lam et al., 2015) and oligodendrocyte differentiation (Carteron, Ferrer-Montiel, \& Cabedo, 2006). Variants of NRG3 are also connected to impulsive actions, delusions and attention deficits (Falls, 2003; Morar et al., 2011).
In conclusion, inter-receptor cross talk is a well-established concept in understanding complex signaling networks and in the translation of environmental conditions into appropriate cell responses. Our results here support the paradigm of inter-receptor crosstalk whereby the transactivation of ErbB4 by $\mathrm{G}_{\mathrm{q}}$-coupled receptors proteins combines the broad diversity of GPCRs with the potent ErbB signaling pathway supporting the maintenance of the radial glial scaffold. (a)

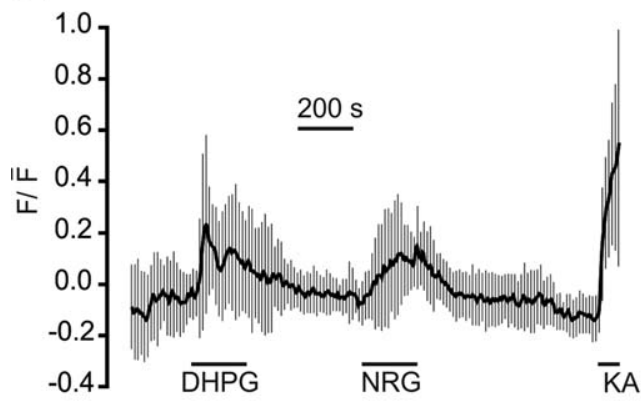

(b)

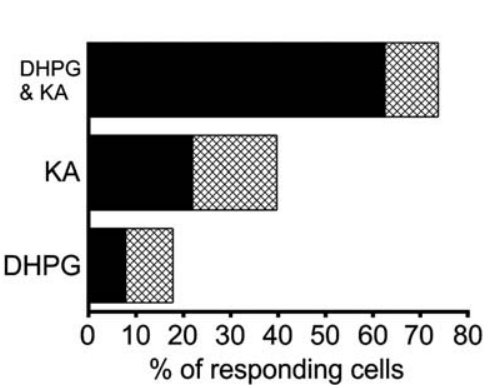

(c)

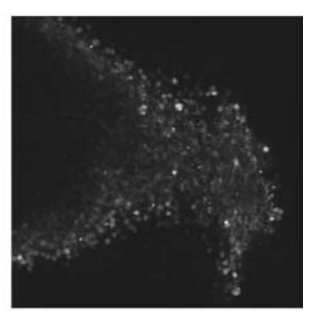

FIGURE 8 Effect of DHPG, NRG and kainate on $\left[\mathrm{Ca}^{2+}\right]_{i}$ in embryonic cortical slabs. The slabs were bulk loaded with fluo-4 and recorded. In a, stimulation was performed with DHPG $(10 \mu \mathrm{M})$, NRG $(100 \mathrm{ng} / \mathrm{ml})$, and kainate $(10 \mu \mathrm{M})$. Average of ROls showing responses to NRG, DHPG, and kainate $(n=15)$ from one slab are shown. Error bars represent $\pm S D$. In $b$, the distribution of the different responses in this slab and the relative response to NRG (hatched). In c, a fluo-4 fluorescence image of the apical surface of the neocortical section 


\section{ACKNOWLEDGMENT}

The authors would like to thank Mr. Jarno Hörhä and Mr. MattiPekka Poikajärvi for their laboratory assistance. This study was supported by Finska Läkaresällskapet, Magnus Ehrnroothin Säätiö, Sigrid Juséliuksen Säätiö, Vetenskapsrådet (grant 2013-3189), Hjarnfonden (grant FO2015-0074), Cancerfonden (grant CAN 2016-801).

\section{CONFLICT OF INTERESTS}

The authors declare no conflict of interest.

\section{ORCID}

Lauri M. Louhivuori (D) http://orcid.org/0000-0001-8649-781X

Pauli M. Turunen (D) http://orcid.org/0000-0002-3129-1678

Karl E. Åkerman (D) http://orcid.org/0000-0003-4625-3081

\section{REFERENCES}

Amaral, M. D., \& Pozzo-Miller, L. (2007). BDNF induces calcium elevations associated with IBDNF, a nonselective cationic current mediated by TRPC channels. Journal of Neurophysiology, 98, 2476-2482. https://doi.org/10.1152/jn.00797.2007

Anton, E. S., Ghashghaei, H. T., Weber, J. L., McCann, C., Fischer, T. M., Cheung, I. D., ... Lai, C. (2004). Receptor tyrosine kinase ErbB4 modulates neuroblast migration and placement in the adult forebrain. Nature Neuroscience, 7, 1319-1328. https://doi.org/10.1038/ nn1345

Anton, E. S., Marchionni, M. A., Lee, K. F., \& Rakic, P. (1997). Role of GGF/neuregulin signaling in interactions between migrating neurons and radial glia in the developing cerebral cortex. Development, 124, 3501-3510.

Asakura, M., Kitakaze, M., Takashima, S., Liao, Y., Ishikura, F., Yoshinaka, T., ... Higashiyama, S. (2002). Cardiac hypertrophy is inhibited by antagonism of ADAM12 processing of HB-EGF: metalloproteinase inhibitors as a new therapy. Nature Medicine, 8, 35-40. https://doi. org/10.1038/nm0102-35

Bean, J. C., Lin, T. W., Sathyamurthy, A., Liu, F., Yin, D. M., Xiong, W. C., \& Mei, L. (2014). Genetic labeling reveals novel cellular targets of schizophrenia susceptibility gene: distribution of GABA and nonGABA ErbB4-positive cells in adult mouse brain. Journal of Neuroscience, 34, 13549-13566. https://doi.org/10.1523/JNEUROSCI. 2021-14.2014

Beerli, R. R., \& Hynes, N. E. (1996). Epidermal growth factor-related peptides activate distinct subsets of ErbB receptors and differ in their biological activities. Journal of Biological Chemistry, 271, 6071-6076.

Berg, A. P., Sen, N., \& Bayliss, D. A. (2007). TrpC3/C7 and Slo2.1 are molecular targets for metabotropic glutamate receptor signaling in rat striatal cholinergic interneurons. Journal of Neuroscience, 27, 8845-8856. https://doi.org/10.1523/JNEUROSCI.0551-07.2007

Birchmeier, C. (2009). ErbB receptors and the development of the nervous system. Experimental Cell Research, 315, 611-618. https://doi. org/10.1016/j.yexcr.2008.10.035

Brauner-Osborne, H., \& Brann, M. R. (1996). Pharmacology of muscarinic acetylcholine receptor subtypes (m1-m5): High throughput assays in mammalian cells. European Journal of Pharmacology, 295, 93-102.

Buonanno, A., \& Fischbach, G. D. (2001). Neuregulin and ErbB receptor signaling pathways in the nervous system. Current Opinion in Neurobiology, 11, 287-296.
Cardenas, A., Kong, M., Alvarez, A., Maldonado, H., \& Leyton, L. (2014). Signaling pathways involved in neuron-astrocyte adhesion and migration. Current Molecular Medicine, 14, 275-290.

Carteron, C., Ferrer-Montiel, A., \& Cabedo, H. (2006). Characterization of a neural-specific splicing form of the human neuregulin 3 gene involved in oligodendrocyte survival. Journal of Cell Science, 119, 898-909. https://doi.org/10.1242/jcs.02799

Castren, M., Tervonen, T., Karkkainen, V., Heinonen, S., Castren, E., Larsson, K., ... Akerman, K. (2005). Altered differentiation of neural stem cells in fragile $X$ syndrome. Proceedings of the National Academy of Sciences of the United States of America, 102, 17834-17839. https:// doi.org/10.1073/pnas.0508995102

Daub, H., Weiss, F. U., Wallasch, C., \& Ullrich, A. (1996). Role of transactivation of the EGF receptor in signalling by G-protein-coupled receptors. Nature, 379, 557-560. https://doi.org/10.1038/379557a0

Di Giorgi Gerevini, V. D., Caruso, A., Cappuccio, I., Ricci Vitiani, L., Romeo, S., Della Rocca, C., ... Nicoletti, F. (2004). The mGlu5 metabotropic glutamate receptor is expressed in zones of active neurogenesis of the embryonic and postnatal brain. Brain Research. Developmental Brain Research, 150, 17-22. https://doi.org/10.1016/j. devbrainres.2004.02.003

Eguchi, S., Numaguchi, K., Iwasaki, H., Matsumoto, T., Yamakawa, T., Utsunomiya, H., ... Inagami, T. (1998). Calcium-dependent epidermal growth factor receptor transactivation mediates the angiotensin IIinduced mitogen-activated protein kinase activation in vascular smooth muscle cells. The Journal of Biological Chemistry, 273, 88908896.

Falls, D. L. (2003). Neuregulins: functions, forms, and signaling strategies. Experimental Cell Research, 284, 14-30.

Feng, L., \& Heintz, N. (1995). Differentiating neurons activate transcription of the brain lipid-binding protein gene in radial glia through a novel regulatory element. Development, 121, 1719-1730.

Fox, I. J., \& Kornblum, H. I. (2005). Developmental profile of ErbB receptors in murine central nervous system: implications for functional interactions. Journal of Neuroscience Research, 79, 584-597. https:// doi.org/10.1002/jnr.20381

Gasser, U. E., \& Hatten, M. E. (1990). Neuron-glia interactions of rat hippocampal cells in vitro: glial-guided neuronal migration and neuronal regulation of glial differentiation. Journal of Neuroscience, 10, 12761285.

Gierdalski, M., Sardi, S. P., Corfas, G., \& Juliano, S. L. (2005). Endogenous neuregulin restores radial glia in a (ferret) model of cortical dysplasia. Journal of Neuroscience, 25, 8498-8504. https://doi.org/10.1523/ JNEUROSCI.1476-05.2005

Graus-Porta, D., Beerli, R. R., Daly, J. M., \& Hynes, N. E. (1997). ErbB-2, the preferred heterodimerization partner of all ErbB receptors, is a mediator of lateral signaling. EMBO J, 16, 1647-1655. https://doi. org/10.1093/emboj/16.7.1647

Gschwind, A., Zwick, E., Prenzel, N., Leserer, M., \& Ullrich, A. (2001). Cell communication networks: epidermal growth factor receptor transactivation as the paradigm for interreceptor signal transmission. Oncogene, 20, 1594-1600. https://doi.org/10.1038/sj.onc.1204192

Harteneck, C., \& Gollasch, M. (2011). Pharmacological modulation of diacylglycerol-sensitive TRPC3/6/7 channels. Current Pharmaceutical Biotechnology, 12, 35-41.

Hunter, K. E., \& Hatten, M. E. (1995). Radial glial cell transformation to astrocytes is bidirectional: regulation by a diffusible factor in embryonic forebrain. Proceedings of the National Academy of Sciences of the United States of America, 92, 2061-2065.

Janisch, K. M., Vock, V. M., Fleming, M. S., Shrestha, A., Grimsley-Myers, C. M., Rasoul, B. A., ... Dwyer, N. D. (2013). The vertebrate-specific 
Kinesin-6, Kif20b, is required for normal cytokinesis of polarized cortical stem cells and cerebral cortex size. Development, 140, 46724682. https://doi.org/10.1242/dev.093286

Jansson, L. C., Louhivuori, L., Wigren, H. K., Nordstrom, T., Louhivuori, V., Castren, M. L., \& Akerman, K. E. (2012). Brain-derived neurotrophic factor increases the motility of a particular N-methyl-D-aspartate/GABA-responsive subset of neural progenitor cells. Neuroscience, 224, 223-234. https://doi.org/10.1016/j.neuroscience. 2012.08.038

Jansson, L. C., Louhivuori, L., Wigren, H. K., Nordstrom, T., Louhivuori, V., Castren, M. L., \& Akerman, K. E. (2013). Effect of glutamate receptor antagonists on migrating neural progenitor cells. European Journal of Neuroscience, 37, 1369-1382. https://doi.org/10.1111/ejn. 12152

Jones, A. R., Overly, C. C., \& Sunkin, S. M. (2009). The Allen Brain Atlas: 5 years and beyond. Nature Reviews Neuroscience, 10, 821-828. https://doi.org/10.1038/nrn2722

Kao, S. C., Wu, H., Xie, J., Chang, C. P., Ranish, J. A., Graef, I. A., \& Crabtree, G. R. (2009). Calcineurin/NFAT signaling is required for neuregulin-regulated Schwann cell differentiation. Science, 323, 651654. https://doi.org/10.1126/science.1166562

Karkkainen, V., Louhivuori, V., Castren, M. L., \& Akerman, K. E. (2009). Neurotransmitter responsiveness during early maturation of neural progenitor cells. Differentiation, 77, 188-198. https://doi.org/10. 1016/j.diff.2008.10.005

Kim, S. J., Kim, Y. S., Yuan, J. P., Petralia, R. S., Worley, P. F., \& Linden, D. J. (2003). Activation of the TRPC1 cation channel by metabotropic glutamate receptor mGluR1. Nature, 426, 285-291. https://doi.org/ 10.1038/nature02162

Kiyonaka, S., Kato, K., Nishida, M., Mio, K., Numaga, T., Sawaguchi, Y., ... Mori, Y. (2009). Selective and direct inhibition of TRPC3 channels underlies biological activities of a pyrazole compound. Proceedings of the National Academy of Sciences of the United States of America, 106, 5400-5405. https://doi.org/10.1073/pnas.0808793106

Kriegstein, A., \& Alvarez-Buylla, A. (2009). The glial nature of embryonic and adult neural stem cells. Annual Review of Neuroscience, 32, 149184. https://doi.org/10.1146/annurev.neuro.051508.135600

Kukkonen, J. P., Lund, P. E., \& Akerman, K. E. (2001). 2-aminoethoxydiphenyl borate reveals heterogeneity in receptor-activated $\mathrm{Ca}(2+)$ discharge and store-operated $\mathrm{Ca}(2+)$ influx. Cell Calcium, 30, 117-129. https://doi.org/10.1054/ceca.2001.0219

Larsson, K. P., Peltonen, H. M., Bart, G., Louhivuori, L. M., Penttonen, A., Antikainen, M., ... Akerman, K. E. (2005). Orexin-A-induced Ca2+ entry: evidence for involvement of trpc channels and protein kinase C regulation. The Journal of Biological Chemistry, 280, 1771-1781. https://doi.org/10.1074/jbc.M406073200

Li, H., Chou, S. J., Hamasaki, T., Perez-Garcia, C. G., \& O'Leary, D. D. (2012). Neuregulin repellent signaling via ErbB4 restricts GABAergic interneurons to migratory paths from ganglionic eminence to cortical destinations. Neural Development, 7, 10. https://doi.org/10.1186/ 1749-8104-7-10

Li, H. S., Xu, X. Z., \& Montell, C. (1999). Activation of a TRPC3dependent cation current through the neurotrophin BDNF. Neuron, 24, 261-273.

Lopez-Bendito, G., Cautinat, A., Sanchez, J. A., Bielle, F., Flames, N., Garratt, A. N., ... Garel, S. (2006). Tangential neuronal migration controls axon guidance: a role for neuregulin-1 in thalamocortical axon navigation. Cell, 125, 127-142. https://doi.org/10.1016/j.cell.2006.01. 042

Louhivuori, L. M., Jansson, L., Turunen, P. M., Jantti, M. H., Nordstrom, T., Louhivuori, V., \& Akerman, K. E. (2015). Transient receptor potential channels and their role in modulating radial glial-neuronal interaction: a signaling pathway involving mGluR5. Stem Cells Development, 24, 701-713. https://doi.org/10.1089/scd.2014.0209

Louhivuori, L. M., Louhivuori, V., Wigren, H. K., Hakala, E., Jansson, L. C., Nordstrom, T., ... Akerman, K. E. (2013). Role of low voltage activated calcium channels in neuritogenesis and active migration of embryonic neural progenitor cells. Stem Cells Development, 22, 12061219. https://doi.org/10.1089/scd.2012.0234

Marin, O., \& Rubenstein, J. L. (2001). A long, remarkable journey: tangential migration in the telencephalon. Nature Reviews Neuroscience, 2, 780-790. https://doi.org/10.1038/35097509

Mei, L., \& Nave, K. A. (2014). Neuregulin-ERBB signaling in the nervous system and neuropsychiatric diseases. Neuron, 83, 27-49. https:// doi.org/10.1016/j.neuron.2014.06.007

Mei, L., \& Xiong, W. C. (2008). Neuregulin 1 in neural development, synaptic plasticity and schizophrenia. Nature Reviews Neuroscience, 9, 437-452. https://doi.org/10.1038/nrn2392

Meijering, E., Dzyubachyk, O., \& Smal, I. (2012). Methods for cell and particle tracking. Methods in Enzymology, 504, 183-200. https://doi. org/10.1016/B978-0-12-391857-4.00009-4

Merritt, J. E., Armstrong, W. P., Benham, C. D., Hallam, T. J., Jacob, R., Jaxa-Chamiec, A., ... Rink, T. J. (1990). SK\&F 96365, a novel inhibitor of receptor-mediated calcium entry. Biochemical Journal, 271, 515-522.

Morar, B., Dragovic, M., Waters, F. A., Chandler, D., Kalaydjieva, L., \& Jablensky, A. (2011). Neuregulin 3 (NRG3) as a susceptibility gene in a schizophrenia subtype with florid delusions and relatively spared cognition. Molecular Psychiatry, 16, 860-866. https://doi.org/10. 1038/mp.2010.70

Noctor, S. C., Flint, A. C., Weissman, T. A., Dammerman, R. S., \& Kriegstein, A. R. (2001). Neurons derived from radial glial cells establish radial units in neocortex. Nature, 409, 714-720. https://doi.org/10. 1038/35055553

Oettling, G., Gotz, U., \& Drews, U. (1992). Characterization of the Ca2+ influx into embryonic cells after stimulation of the embryonic muscarinic receptor. Journal of Developmental Physiology, 17, 147-155.

Ohtsu, H., Dempsey, P. J., \& Eguchi, S. (2006). ADAMs as mediators of EGF receptor transactivation by $G$ protein-coupled receptors. American Journal of Physiology Cell Physiology, 291, C1-C10. https://doi. org/10.1152/ajpcell.00620.2005

Ozaki, M., Itoh, K., Miyakawa, Y., Kishida, H., \& Hashikawa, T. (2004). Protein processing and releases of neuregulin-1 are regulated in an activity-dependent manner. Journal of Neurochemistry, 91, 176-188. https://doi.org/10.1111/j.1471-4159.2004.02719.x

Ozaki, M., Sasner, M., Yano, R., Lu, H. S., \& Buonanno, A. (1997). Neuregulin-beta induces expression of an NMDA-receptor subunit. Nature, 390, 691-694. https://doi.org/10.1038/37795

Pinkas-Kramarski, R., Shelly, M., Glathe, S., Ratzkin, B. J., \& Yarden, Y. (1996). Neu differentiation factor/neuregulin isoforms activate distinct receptor combinations. Journal of Biological Chemistry, 271 , 19029-19032.

Plani-Lam, J. H., Chow, T. C., Siu, K. L., Chau, W. H., Ng, M. H., Bao, S., ... Song, Y. Q. (2015). PTPN21 exerts pro-neuronal survival and neuritic elongation via ErbB4/NRG3 signaling. The International Journal of Biochemistry \& Cell Biology, 61, 53-62. https://doi.org/10.1016/j.biocel.2015.02.003

Prenzel, N., Zwick, E., Daub, H., Leserer, M., Abraham, R., Wallasch, C., \& Ullrich, A. (1999). EGF receptor transactivation by G-protein-coupled receptors requires metalloproteinase cleavage of proHB-EGF. Nature, 402, 884-888. https://doi.org/10.1038/47260 
Rakic, P. (1971). Neuron-glia relationship during granule cell migration in developing cerebellar cortex. A Golgi and electronmicroscopic study in Macacus Rhesus. Journal of Comparative Neurology, 141, 283-312. https://doi.org/10.1002/cne.901410303

Reynolds, B. A., \& Weiss, S. (1992). Generation of neurons and astrocytes from isolated cells of the adult mammalian central nervous system. Science, 255, 1707-1710.

Rio, C., Rieff, H. I., Qi, P., Khurana, T. S., \& Corfas, G. (1997). Neuregulin and erbB receptors play a critical role in neuronal migration. Neuron, 19, 39-50.

Saito, S., Frank, G. D., Motley, E. D., Dempsey, P. J., Utsunomiya, H., Inagami, T., \& Eguchi, S. (2002). Metalloprotease inhibitor blocks angiotensin II-induced migration through inhibition of epidermal growth factor receptor transactivation. Biochemical and Biophysical Research Communnications, 294, 1023-1029. https://doi.org/10.1016/S0006291X(02)00595-8

Santiskulvong, C., \& Rozengurt, E. (2003). Galardin (GM 6001), a broadspectrum matrix metalloproteinase inhibitor, blocks bombesin- and LPA-induced EGF receptor transactivation and DNA synthesis in rat1 cells. Experimental Cell Research, 290, 437-446.

Schindelin, J., Arganda-Carreras, I., Frise, E., Kaynig, V., Longair, M., Pietzsch, T., ... Cardona, A. (2012). Fiji: an open-source platform for biological-image analysis. Nature Methods, 9, 676-682. https://doi. org/10.1038/nmeth.2019

Schmid, R. S., McGrath, B., Berechid, B. E., Boyles, B., Marchionni, M., Sestan, N., \& Anton, E. S. (2003). Neuregulin 1-erbB2 signaling is required for the establishment of radial glia and their transformation into astrocytes in cerebral cortex. Proceedings of the National Academy of Sciences of the United States of America, 100, 4251-4256. https://doi.org/10.1073/pnas.0630496100

Schneider, C. A., Rasband, W. S., \& Eliceiri, K. W. (2012). NIH Image to ImageJ: 25 years of image analysis. Nature Methods, 9, 671-675.

Sild, M., \& Ruthazer, E. S. (2011). Radial glia: progenitor, pathway, and partner. Neuroscientist, 17, 288-302. https://doi.org/10.1177/ 1073858410385870

Thompson, C. L., Ng, L., Menon, V., Martinez, S., Lee, C. K., Glattfelder, K., ... Jones, A. R. (2014). A high-resolution spatiotemporal atlas of gene expression of the developing mouse brain. Neuron, 83, 309323. https://doi.org/10.1016/j.neuron.2014.05.033

Tsai, W., Morielli, A. D., \& Peralta, E. G. (1997). The m1 muscarinic acetylcholine receptor transactivates the EGF receptor to modulate ion channel activity. EMBO J, 16, 4597-4605. https://doi.org/10.1093/ emboj/16.15.4597

Xu, S. Z., Zeng, F., Boulay, G., Grimm, C., Harteneck, C., \& Beech, D. J. (2005). Block of TRPC5 channels by 2-aminoethoxydiphenyl borate: a differential, extracellular and voltage-dependent effect. Briticsh Journal of Pharmacology, 145, 405-414. https://doi.org/10.1038/sj. bjp.0706197

Yeromin, A. V., Zhang, S. L., Jiang, W., Yu, Y., Safrina, O., \& Cahalan, M. D. (2006). Molecular identification of the CRAC channel by altered ion selectivity in a mutant of Orai. Nature, 443, 226-229. https:// doi.org/10.1038/nature05108

Zheng, C. H., \& Feng, L. (2006). Neuregulin regulates the formation of radial glial scaffold in hippocampal dentate gyrus of postnatal rats. Journal of Cell Physiology, 207, 530-539. https://doi.org/10.1002/jcp. 20591

Zwick, E., Daub, H., Aoki, N., Yamaguchi-Aoki, Y., Tinhofer, I., Maly, K., \& Ullrich, A. (1997). Critical role of calcium- dependent epidermal growth factor receptor transactivation in PC12 cell membrane depolarization and bradykinin signaling. Journal of Biological Chemistry, 272, 24767-24770.

\section{SUPPORTING INFORMATION}

Additional Supporting Information may be found online in the supporting information tab for this article.

How to cite this article: Louhivuori LM, Turunen PM, Louhivuori $\mathrm{V}$, et al. Regulation of radial glial process growth by glutamate via mGluR5/TRPC3 and neuregulin/ErbB4. Glia. 2018;66:94-107. https://doi.org/10.1002/glia.23230 